\title{
Adaptation of TIMES Model Structure to Industrial, Commercial and Residential Sectors
}

\author{
Dzintars JAUNZEMS ${ }^{1 *}$, Ieva PAKERE ${ }^{2}$, Signe ALLENA-OZOLIN,A ${ }^{3}$, Ritvars FREIMANIS ${ }^{4}$, \\ Andra BLUMBERGA ${ }^{5}$, Gatis BAŽBAUERS ${ }^{6}$ \\ ${ }^{1-6}$ Institute of Energy Systems and Environment, Riga Technical University, Azenes iela 12/1, Riga, Latvia
}

\begin{abstract}
National energy sector management differs from country to country. Therefore, it is important to develop country-specific energy models to analyse the energy demand, structure and potential policy instruments. The paper presents a pathway for adaption and improvement of the standard TIMES model structure to the specific country requirements. The analysis is based on a three-sector (industrial, commercial and residential) case study of Latvia. Literature review presents experience of other research when developing different energy models as well as adapting the TIMES model structure. The main results show a distribution of the final energy consumption and the validation of the obtained results of the sectors studied. Method and intermediate results presented in the paper are part of an ongoing modelling process of Latvia's energy sector.
\end{abstract}

Keywords - Energy system modelling; final energy consumption; optimization bottom-up model, TIMES model.

\section{INTRODUCTION}

Consequences of global warming have become more realistic and more prominent in all regions. Therefore, policy makers implement various laws, regulations, policy measures and other regulatory frameworks to limit increase of the global average temperature. Energy production is one of the main driver of global warming which is related to all other sectors.

Different energy models can play a crucial role when developing energy planning strategies. Researchers from China have created the multi-sectoral energy model merging electricity, transportation, heat and industrial sectors to model decarbonisation of an energy system [1]. Often researchers combine different types of models, for example, technically detailed bottom-up and top-down models that simulate demand and prices on energy [2], [3]. The system dynamic approach has been used to model the transition from fossil fuels to renewable energy resources by taking into account different techno-economic parameters, political and social aspects, as well as human behavior [4].

In many countries, sector-specific energy models have been developed, for example, the household sector model which analyses and evaluates implementation of renewable energy systems for regional demand [5]. Many simulations are performed to identify heat demand and to simulate future demand by clustering of the residential sector in the UK [6]. Also in Quebec (Canada), electricity supply of households, which are already low-carbon, have been modelled by combined building model simulations to investigate mitigation opportunities of greenhouse gases (GHG) [7].

* Corresponding author.

E-mail address: Dzintars.Jaunzems@ @rtu.lv 
Less models have been developed for the industrial sector. Researchers have modeled the potential energy savings and decrease of $\mathrm{CO}_{2}$ emission in iron and steel industry by using a bottom-up linear optimization model [8]. Another bottom-up model has been developed for industrial sector of Denmark [9]. The highly technologically detailed FORECAST bottom-up model has been created to simulate energy perspectives and develop scenarios for energy sector decarbonisation [10].

In many countries, researchers have used the Integrated MARKAL-EFOM System (TIMES) model generator to analyse local, national and global energy systems and potential to reach the climate targets. In most cases, the basic sectoral structure of TIMES needs to be adjusted and modified to represent the country-specific energy system. German researchers have developed the TIMES model to improve decision-making related to investments. In the adapted energy model, the country is divided into four regions, but investors - into three groups depending on the costs of capital and budget restrictions [11].

The energy system model has also been created for Denmark. The model divides the country into two energy regions - Denmark East and Denmark West and covers five sectors - supply, power and heat, industrial, residential and transport. The year has been divided into 32 time slices representing four seasons, weekly and daily variations. That increases the variability of the model regarding heating demands, availability of intermittent renewable energy sources and technologies like solar PV and wind turbines. In addition, efficiency of large-scale heat pumps is assumed to be dependent on outdoor temperature. Import and export prices are divided into 32 time slices as well. Authors divide the residential sector according to the building type and construction period, district heating (DH) area and regions resulting in 36 building groups. In contrast, the industry sector is divided into 12 sectors, covering primary, secondary and tertiary sectors. Transport sector has two large groups - passenger and freight, divided into aviation, maritime and inland. Inland passenger transport has been divided into eight modes including cars, buses, railway, motorcycle and non-motorised modes like walking and biking [12].

British researchers have developed a model framework in the UK for residential sector in TIMES to analyse homeowner preferences for heating technologies. Households were divided into three groups depending on number of bedrooms and into four groups depending on the existing heating technologies - gas heaters, electric heaters, heat pumps and solid fuel boilers. In this model 16 time slices have been used representing four seasons and four day splits [13].

Although TIMES is a powerful modelling tool, some articles discuss the need to take into account not only technology development but also feedback loops, social behavioral changes and other factors [14]. Some TIMES models have been improved by adding consumer behavior in the optimization model using social surveys [13], [15], [16].

Models are important to increase the quality of research, reduce duplication of work, and there are other benefits [17]. Above all, a representative model is based on the transparency and availability of data. Therefore, this paper presents the TIMES model structure of three different sectors and the methodology, which has been used to determine energy consumption division for different end-use processes.

The main aim of the paper is to present structural adoption of the TIMES model to industrial (IND), commercial (COM) and residential (RSD) sectors of Latvia. The article also presents the necessary data gathering. Along with sectoral specific changes this structure can be adopt to other countries. As far as authors know this is the first TIMES model of Latvia case. Previously there were used MARKAL and MARKAL-TIMES models for Latvia. 


\section{METHODOLOGY}

This section presents the methodology for adopting and adjusting the TIMES structure to Latvia's IND, COM and RSD sectors.

TIMES vertically integrated model generator is used to model different energy systems local, national or global. It aims to find the minimum global costs for energy services considering different input data: energy service demands, estimates of the existing energy stocks, properties of the existing equipment and future technologies. Furthermore, TIMES allows to analyse different energy and environmental scenarios and policy measures [18].

\subsection{Industry sector}

Latvia is a part of the European Union emission trading system (ETS). Therefore, energy demand of almost each IND sector in Latvia has been divided into ETS sector and non-ETS sector consumption (see Table 1). The ETS system of Latvia mostly covers power plants and other incineration plants with nominal thermal input of more than $20 \mathrm{MW}$. Also specific equipment, like coke ovens, iron and steel, cement clinker and others technologies, are included in the ETS system [19]. In 2017, the ETS sector covered around $15.5 \%$ of the total resource demand in Latvia equal to 5561 TJ. Non-ETS covered the rest of demand, i.e. $84.5 \%$ or 30335 TJ [20].

TABLE 1. IND SUB-SECTORS IN LATVIA

\begin{tabular}{|c|c|c|c|c|c|c|c|c|c|c|c|}
\hline & 1 & 2 & 3 & 4 & 5 & & 1 & 2 & 3 & 4 & 5 \\
\hline Iron and steel & & $\vee$ & $\vee$ & $\vee$ & $\vee$ & Mining ETS & & & $\vee$ & $\vee$ & \\
\hline Iron and steel ETS & & & $\vee$ & $\vee$ & & Paper, pulp and print (Paper) & & $\vee$ & $\vee$ & $\vee$ & $\vee$ \\
\hline $\begin{array}{l}\text { Chemical and chemical } \\
\text { products (Chemical) }\end{array}$ & $\vee$ & $\vee$ & $\vee$ & $\vee$ & $\vee$ & $\begin{array}{l}\text { Wood and wood products } \\
\text { (Wood processing) }\end{array}$ & $\vee$ & $\vee$ & $\vee$ & $\vee$ & $\vee$ \\
\hline Chemical ETS & & & $\vee$ & $\vee$ & & Wood processing ETS & & & $\vee$ & $\vee$ & \\
\hline Non-ferrous metals & & $\vee$ & $\vee$ & $\vee$ & $\vee$ & Food and tobacco & $\vee$ & $\vee$ & $\vee$ & $\vee$ & $\vee$ \\
\hline Non-metallic minerals & & $\vee$ & $\vee$ & $\vee$ & $\vee$ & Food and tobacco ETS & & & $\vee$ & $\vee$ & \\
\hline Non-metallic minerals ETS & & & $\vee$ & $\vee$ & & Construction & $\vee$ & $\vee$ & $\vee$ & V & $\vee$ \\
\hline Transport equipment & $\vee$ & $\vee$ & $\vee$ & $\vee$ & $\vee$ & Construction ETS & & & $\vee$ & $\vee$ & \\
\hline Transport equipment ETS & & & $\vee$ & & & Textile and leather (Textile) & & $\vee$ & $\vee$ & $\vee$ & $\vee$ \\
\hline Machinery & & $\vee$ & $\vee$ & $\vee$ & $\vee$ & Textile ETS & & & $\vee$ & $\vee$ & \\
\hline $\begin{array}{l}\text { Mining and quarrying } \\
\text { (Mining) }\end{array}$ & & $\vee$ & $\vee$ & $\vee$ & $\vee$ & $\begin{array}{l}\text { Other - rubber, plastic } \\
\text { furniture and others (Other) }\end{array}$ & $\vee$ & $\vee$ & $\vee$ & $\vee$ & $\vee$ \\
\hline
\end{tabular}

1 - feedstock, 2 - machine drive, 3 - process heat, 4 - building heat, hot water,

5 - cooling, lighting, ventilation, other

Five different end-use processes have been analysed in the IND sector: feedstock, machine drive, process heat, building heat and hot water, and other processes, including cooling, lighting and ventilation (Table 1). For some sectors (Chemical production, Transport equipment) all processes have been analysed but for sectors included in ETS only two processes (process heat, building heat and hot water) have been included due to specific plants.

To determine a share of the total energy sources used for each process, authors used the data from the IND energy audits carried out in the period 2016-2018. The energy balances 
from 122 different enterprises have been analysed to identify the distribution of various energy sources.

\subsection{Commercial sector}

There are different buildings and resulting consumption levels of energy resources in the COM sector. Therefore, it has been divided into seven sub-sectors (see Table 2) based on the building classification [21].

Resource consumption for almost all COM sub-sectors has been divided into ten processes: heating, cooling, cooking, lighting, public lighting, refrigeration, ventilation, water heating, office equipment and other. New process of heating and cooling demand was created - heating and cooling area $\left(\mathrm{m}^{2}\right)$ to add more precise policy measures directly to energy efficiency of specific buildings. To ensure correct process development in TIMES model, heating and cooling processes have been separated as pre-process for heating and cooling area which now have been defined as end demand (see Fig. 1).

TABLE 2. COM SUB-SECTORS IN LATVIA

\begin{tabular}{|c|c|c|c|c|}
\hline \multirow{2}{*}{ Sector } & \multicolumn{2}{|c|}{$\begin{array}{l}\text { Total energy consumption in } \\
2017\end{array}$} & \multicolumn{2}{|c|}{ Total area in 2017} \\
\hline & $\mathrm{TJ}$ & $\%$ & $\mathrm{~m}^{2}$ & $\%$ \\
\hline Wholesale and retail buildings (Retail) & 4085 & 16.04 & 4920 & 15.90 \\
\hline Office buildings (Offices) & 4893 & 19.21 & 6510 & 21.03 \\
\hline Hotel buildings (Hotels) & 2511 & 9.86 & 2310 & 7.46 \\
\hline $\begin{array}{l}\text { Schools, universities and research buildings } \\
\text { (Educational) }\end{array}$ & 5144 & 20.20 & 6940 & 22.42 \\
\hline $\begin{array}{l}\text { Buildings for medical or health care facilities } \\
\text { (Medical) }\end{array}$ & 2281 & 8.96 & 2020 & 6.53 \\
\hline $\begin{array}{l}\text { Entertainment event, sports buildings, museums, } \\
\text { cultural buildings, cultural and historical sites } \\
\text { (Entertainment) }\end{array}$ & 2506 & 9.84 & 3320 & 10.73 \\
\hline $\begin{array}{l}\text { Other - garages, communication centres, stations, } \\
\text { terminals etc. (Other) }\end{array}$ & 3344 & 13.13 & 4930 & 15.93 \\
\hline COM ETS & 704 & 2.76 & - & - \\
\hline Total & 25468 & 100.00 & 30950 & 100.00 \\
\hline
\end{tabular}

Similar to other demand processes, demand for heating and cooling area $\left(\mathrm{m}^{2}\right)$ has been affected by demand drivers like GDP growth and elasticity for evolution with GDP. Specific plants appear in COM sector as ETS participants. Those mainly ensure different manufacturing processes. In TIMES model, they have been divided separately with similar processes to IND sector - process heat and building heat, and hot water (Fig. 1).

The available statistical data only presents the total consumption of primary energy sources, and heat and power consumption in overall COM sector. Therefore, the specific consumption for different end use purposes has been determined through several assumptions and calculations. 


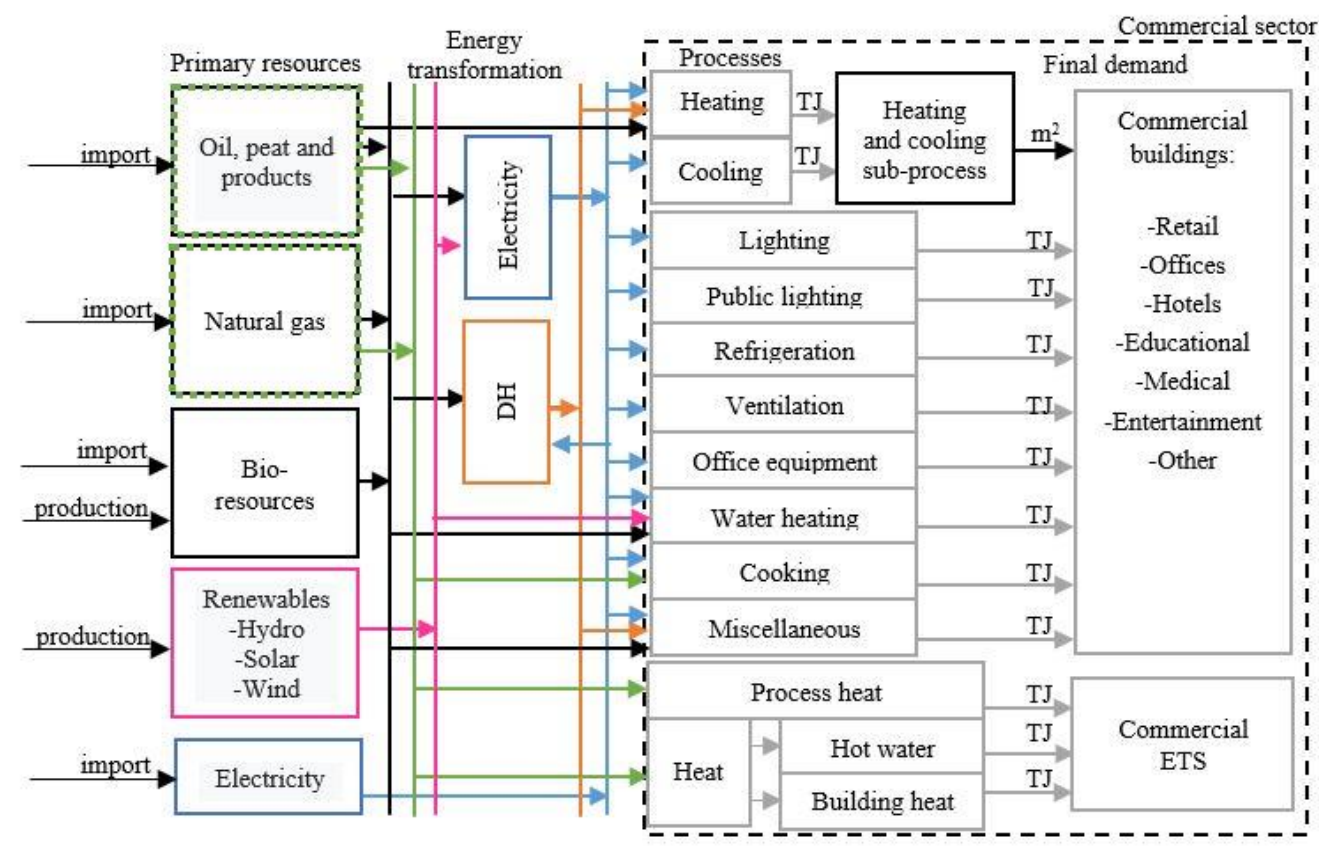

Fig. 1. Process scheme of COM sector.

The main input data for calculations is the total floor area of different types of buildings offices, hotels and restaurants, schools, universities and research buildings (education), hospitals and buildings for health care facilities (medical), buildings for entertainment even ts and sports, museums, cultural and historical sites (entertainment) and other not previously classified buildings. Table 3 summarizes the main assumptions related to energy consumption distribution.

TABLE 3. ASSUMPTIONS FOR ENERGY DISTRIBUTION IN COM SECTOR

\begin{tabular}{|c|c|c|c|c|c|c|c|}
\hline Parameter & 胥 & 氖 & 茪 & 氖 & 矛 & 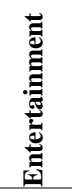 & 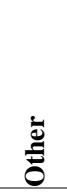 \\
\hline Share of heated area & $85 \%$ & $80 \%$ & $75 \%$ & $80 \%$ & $80 \%$ & $70 \%$ & $30 \%$ \\
\hline \multicolumn{8}{|l|}{$\begin{array}{l}\text { Specific heat consumption for space } \\
\text { heating, } \mathrm{kWh} / \mathrm{m}^{2}\end{array}$} \\
\hline Existing buildings & 130 & 140 & 135 & 160 & 160 & 150 & 120 \\
\hline Renovated buildings & 110 & & & & & & \\
\hline Newly built buildings & 100 & & & & & & \\
\hline $\begin{array}{l}\text { Specific heat consumption for hot } \\
\text { water heating, } \mathrm{kWh} / \mathrm{m}^{2}\end{array}$ & 10 & 10 & 35 & 21 & 24 & 10 & 5 \\
\hline \multicolumn{8}{|l|}{ Share of mechanically ventilated area } \\
\hline Existing buildings & $60 \%$ & $50 \%$ & $50 \%$ & $30 \%$ & $50 \%$ & $30 \%$ & $30 \%$ \\
\hline
\end{tabular}




\begin{tabular}{|c|c|c|c|c|c|c|c|}
\hline Renovated buildings & $70 \%$ & $70 \%$ & $70 \%$ & $50 \%$ & $70 \%$ & $60 \%$ & $40 \%$ \\
\hline Newly-built buildings & $80 \%$ & $80 \%$ & $80 \%$ & $60 \%$ & $80 \%$ & $70 \%$ & $50 \%$ \\
\hline $\begin{array}{l}\text { Power consumption for ventilation, } \\
\mathrm{kWh} / \mathrm{m}^{2}\end{array}$ & 20 & 20 & 20 & 20 & 30 & 30 & 20 \\
\hline \multicolumn{8}{|l|}{$\begin{array}{l}\text { Share of building area with space } \\
\text { cooling }\end{array}$} \\
\hline Existing buildings & $40 \%$ & $50 \%$ & $60 \%$ & $40 \%$ & $40 \%$ & $20 \%$ & $5 \%$ \\
\hline Renovated buildings & $60 \%$ & $70 \%$ & $70 \%$ & $50 \%$ & $70 \%$ & $60 \%$ & $5 \%$ \\
\hline Newly built buildings & $80 \%$ & $80 \%$ & $80 \%$ & $60 \%$ & $80 \%$ & $70 \%$ & $20 \%$ \\
\hline $\begin{array}{l}\text { Specific cooling consumption, } \\
\mathrm{kWh} / \mathrm{m}^{2}\end{array}$ & 53 & 53 & 40 & 40 & 53 & 40 & 20 \\
\hline $\begin{array}{l}\text { Average minimum level of } \\
\text { illumination, lux }\end{array}$ & 369 & 383 & 314 & 352 & 457 & 325 & 291 \\
\hline $\begin{array}{l}\text { Specific power consumption for } \\
\text { lighting, } \mathrm{kWh} / \mathrm{m}^{2}\end{array}$ & 29 & 14 & 12 & 10 & 34 & 13 & 20 \\
\hline
\end{tabular}

Heat consumption for the space heating has been calculated by assuming different levels of building efficiencies (specific heat consumption for space heating) according to available data sources [22], [23], [24]. The renovated and newly built buildings have been separated as those are subject to the specified standards [25]. As it is not necessary to maintain a certain indoor temperature throughout all the buildings, authors assume that only part of the total area is heated. The specific consumption for domestic hot water has been estimated to be greater in hotels and hospitals [26], as there are high washing and cleaning standards applicable.

Some of the buildings are mechanically ventilated to provide the necessary air exchange. Mechanical ventilation is assumed to be more widespread in the new and renovated buildings than in the existing buildings. Power consumption for the ventilation has been calculated similarly as space heating consumption by assuming the share of mechanically ventilated area and the average power consumption for ventilation [27]. Higher values have been assumed for medical and entertainment buildings as these buildings have higher requirements for air exchange rate.

Power consumption for space cooling has been determined according to the methodology presented by Werner [28]. Similar to previous estimations, authors assume the share of the total area, which is cooled during the warmer periods, and the specific cooling consumption of the particular type of building. Higher cooling demands have been assumed in the retail, office and medical buildings [29].

The specific power consumption for lighting has been determined through the minimum level of illumination requirements for different types of buildings [30].

$$
S P C_{\text {lighting }}=\sum \frac{I l_{i} \cdot \beta_{i, j}}{\eta_{j}},
$$

where

$I_{i} \quad$ illumination requirements in building type $i, 1 \mathrm{~m} / \mathrm{m}^{2}$;

$\beta_{i, j} \quad$ share of specific luminaries $j$ used in buildings $i$;

$\eta_{j} \quad$ efficiency of luminaries $j, \mathrm{~lm} / \mathrm{W}$. 
Authors assume that three different types of luminaries are used in COM buildings - LED lighting (average share $44 \%$; average efficiency $100 \mathrm{~lm} / \mathrm{W}$ ), efficient luminaries including luminescent and halogen lamps (average share $43 \%$; average efficiency $56 \mathrm{~lm} / \mathrm{W}$ ) and inefficient luminaries (average share $13 \%$; average efficiency $15 \mathrm{~lm} / \mathrm{W}$ ) [31].

In addition, power consumption for public lighting has been estimated through the correlation analyses (see Fig. 2). Authors have identified power consumption for the public lighting in several cities and towns, mainly presented in the sustainable energy action plans of municipalities.

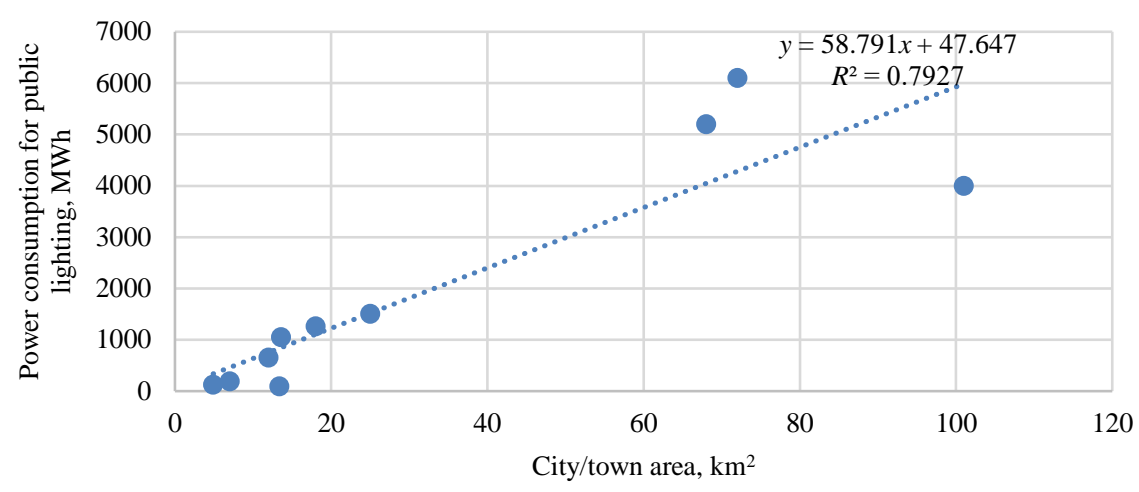

Fig. 2. Regression analyses of power consumption for public lighting depending on the populated area.

As can be seen in Fig. 2, there is a good correlation between power consumption for the public lighting and the city or town area. Application of the regression equation allows estimating the total power consumption for public lighting in all populated areas and includes it in the overall energy balance of COM sector.

\subsection{Residential sector}

The RSD sector was divided into two sections - single-family houses and apartment buildings, as both use different energy resources and differ in their consumption. It is assumed that the single-family houses are not connected to the DH network, but part of the apartment buildings are connected to centralised heat supply.

Processes analysed in TIMES model for RSD sector are heating, cooling, water heating, refrigeration, lighting, cooking, electrical appliances and other applications. New heating and cooling sub-processes are created similarly to the COM sector. This helps to overcome technology linking to a specific type of building and allows to add policy measures related to energy efficiency of buildings more precisely.

In addition, heating and cooling processes have been defined as pre-processes whereas the rest of the processes like cooking, lighting and others are marked as the final demand and will be analysed in different scenarios. There are also researches where surface area of the dwelling stock have been set as a demand driver for heating in the RSD sector but it is not applied in the particular research [32]. 


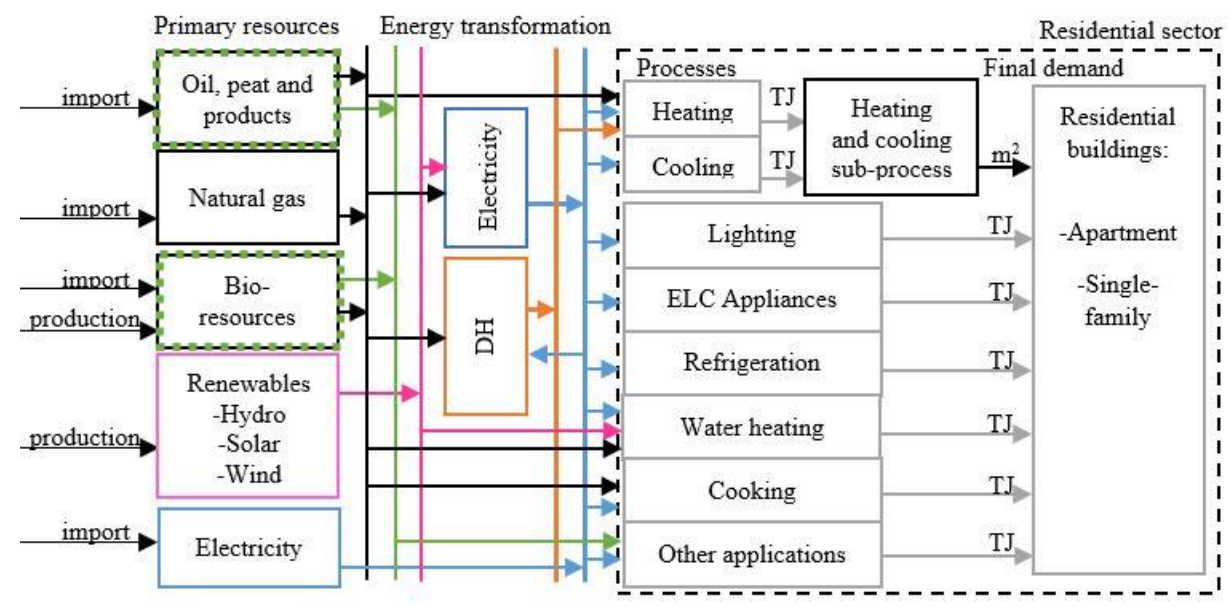

Fig. 3. Process scheme of RSD sector.

\section{Results}

This section presents intermediate results for the base year of 2017 - the used input data and resource allocation for different processes, as well as validation of the model.

\subsection{Data gathering}

\subsubsection{Industrial sector}

The IND sector is the third largest energy consumer in Latvia compiling $21 \%$ of the total final energy used in 2017 of which $38 \%$ were wood biomass, $18 \%$ electricity, $14 \%$ oil products and $13 \%$ natural gas. IND sector in Latvia consists of 13 sub-sectors, of which the most part of energy is used in manufacturing of wood and wood products.

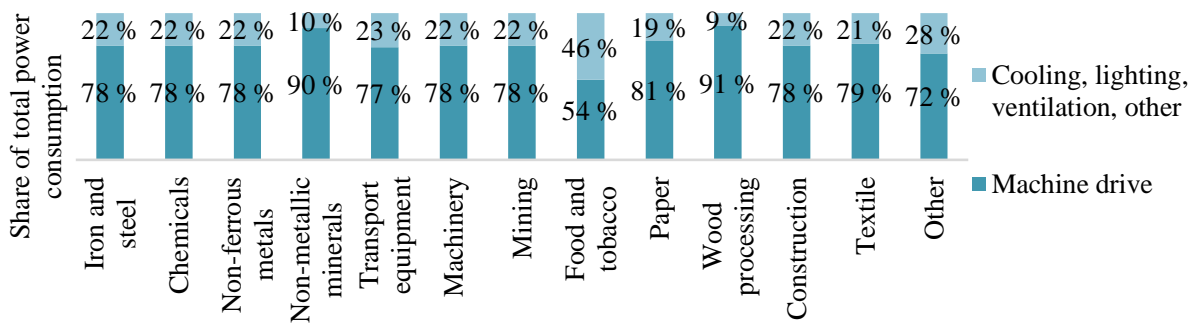

Fig. 4. Power consumption structure in IND sub-sectors.

Power consumption in the IND sector in the TIMES model has been divided into two large parts - electricity used for machine drive, to ensure manufacturing processes, and auxiliary processes - cooling, lighting, ventilation and other power consuming processes. In most of the IND sub-sectors, around $77 \%$ to $81 \%$ of power is used for machine drive (see Fig. 4). Higher share of electricity consumption for machine drive is in the sub-sectors of non-metallic minerals and wood processing industries. In contrast, the lower share of electricity for machine drive is in food and tobacco production - only $54 \%$. 


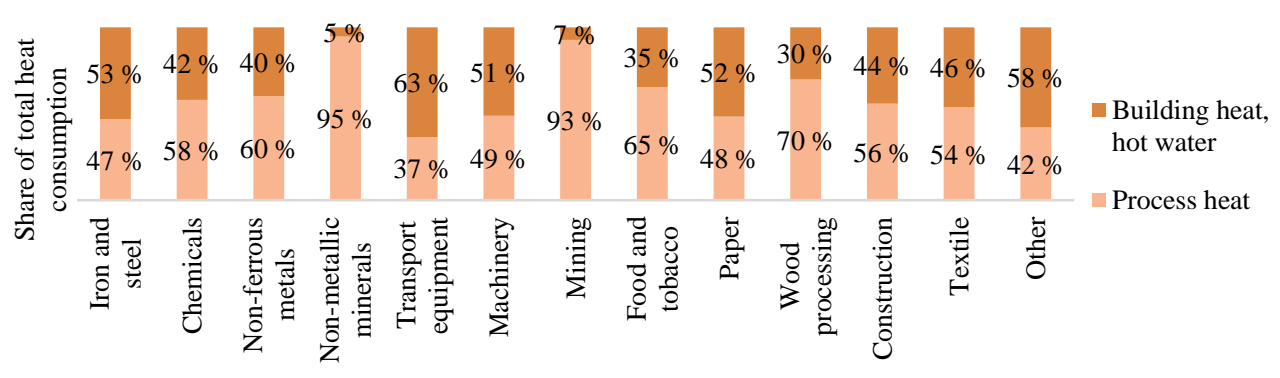

Fig. 5. Heat consumption structure in IND sub-sectors.

Heat consumption in the TIMES model has been divided into thermal energy used for space heating and hot water preparation, and process heat that is used for manufacturing processes. Differences in heat consumption division in sub-sectors are more significant compared to power consumption (see Fig. 5). In some sub-sectors, less than half of the heat is used for process heat (transport equipment production). Nevertheless, there are sub-sectors where even more than $90 \%$ of heat have been used for production processes - non-metallic minerals production and mining.

\subsubsection{Commercial sector}

The COM sector used $15 \%$ of the total final energy in 2017, equal to 25 PJ. COM sector has been divided in seven sectors based on building classification [21]. Power is the main resource used in the COM sector reaching almost $10 \mathrm{PJ}$ and $43 \%$ of the total final electricity consumed in 2017. Also $27 \%$ of the total final natural gas consumption, equal to $3.8 \mathrm{PJ}$, was used in the COM sector, where most of it was consumed in educational buildings and offices (see Fig. 6).

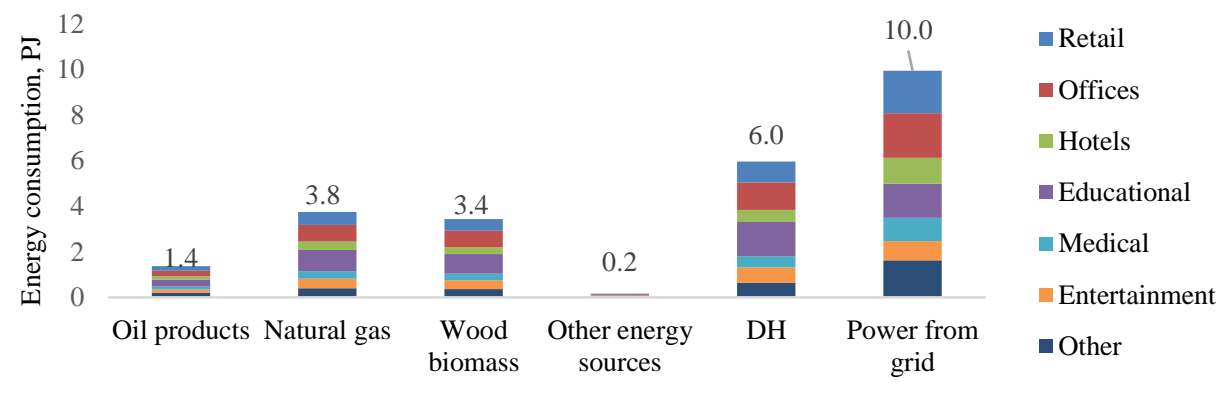

Fig. 6. Resource consumption structure in COM sub-sectors in 2017 [20].

Electricity consumption structure differs in COM sub-sectors (see Fig. 7). In retail buildings as well in buildings for medical facilities and entertainment, most of the electricity is spent for lighting. In office buildings, the office equipment consumes the most power but in hotel and educational buildings most of it is used for water heating. 


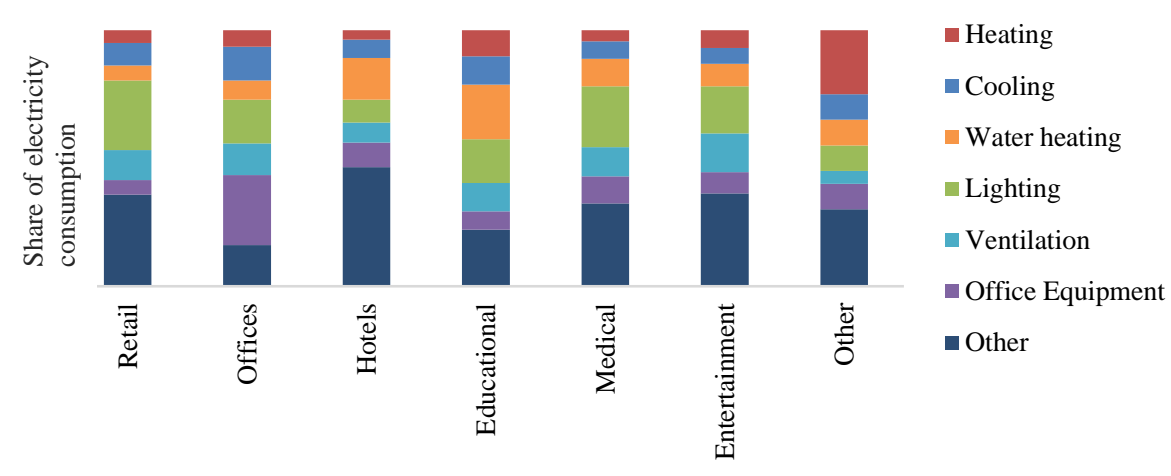

Fig. 7. Electricity consumption structure in the COM sector.

DH and primary energy sources have been used for three processes - water heating, space heating and other processes like cooking. In almost all COM sub-sectors, heating has mainly been used for space heating and only a small share for water heating.

\subsubsection{Residential sector}

The second largest part of the final consumption is dedicated to RSD sector, reaching $29 \%$. Most of it was wood biomass consumption, equal to $21 \mathrm{PJ}$, of which $38 \%$ was used in singlefamily houses and $62 \%$ in apartment buildings (see Fig. 8a).

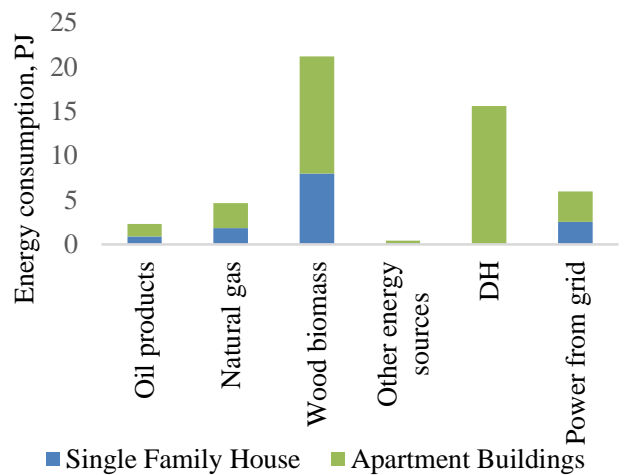

a)

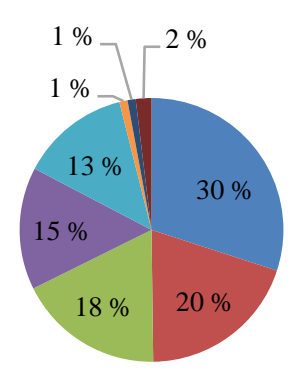

ELC appliances

Water heating

Cooking

- Lighting

Heating

- Cooling

- Refrigeration

- Other applications

b)

Fig. 8. Resource consumption structure (a) and structure of power consumption (b) in RSD sector in 2017.

The structure of electricity consumption is similar in single-family houses and apartment buildings, as consumer behaviour is not depending on the building type. According to Eurostat [33], largest share of electricity, i.e. $30 \%$, is consumed for different electrical appliances (TV, radio, mobile charging etc.), $20 \%$ is used for water heating, $18 \%$ for cooking, $15 \%$ for lighting and $13 \%$ for heating (see Fig. 8b). 


\subsection{Model validation}

In order to validate the developed structure of TIMES model, the modeled results of year 2018 have been compared to the national energy balance. The comparison of statistical data and modelled results can be seen in Fig. 9. The total primary energy consumption difference in RSD and COM sectors is around $3 \%$, but for IND sector the modeled primary energy consumption and actual consumption are equal.

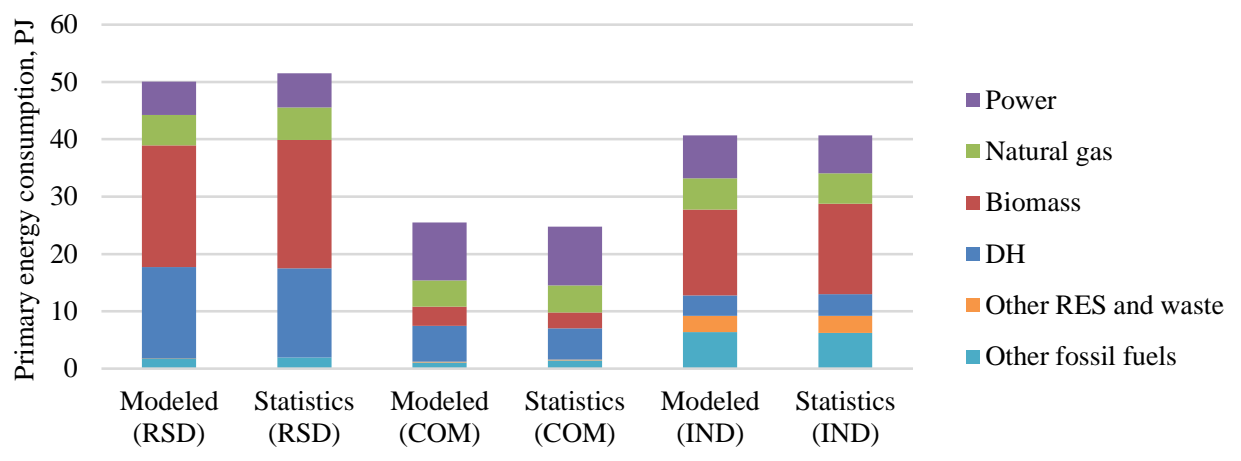

Fig. 9. Validation results analysed in residential, commercial and industry sectors for year 2018.

When evaluating the consumption of particular energy sources the difference of modeled results and statistical data is more prominent. In the RSD sector, the main variance occurs for coal and wood pellet consumption, which is higher in the actual energy balance of 2018 and LPG, which is higher in TIMES model. Similar tendency occurs in COM and IND sectors for coal. TIMES model also forecasts slightly higher increase of power consumption in IND sector than the actual power consumption increase. Such differences arises because the main aim of the model is to optimize the final energy consumption by choosing most efficient technologies and cheapest energy sources which is not always happening in real life. Further validation process could include the comparison of the results for two-year period (2018 and 2019) when the energy balance for 2019 will be available.

\section{Conclusions}

It is important to build up an energy model that represents a country-specific situation. The paper presents the methodology for structure adaption of TIMES model for industrial (IND), commercial (COM) and residential (RSD) sectors in Latvia. Authors have identified the necessary structure changes of standard model to build a representative sectors models. The methodology presents different methods which allows to overcome lack of specific data related to final energy consumption in particular processes. These methods can be used in other countries when developing similar forecasting models.

The intermediate results include energy resource consumption in each of the sectors divided among particular end-processes. The main processes in the IND sector are machine drive and process heat to ensure manufacturing processes, power consuming auxiliary processes (cooling, lighting, ventilation and other) and space heating, and hot water preparation. The COM sector has been divided in 7 sub-sectors depending on the functions of particular buildings (educational, medical, retail, hotel, entertainment, offices and others). Ten different end-processes have been included in the COM sector model. The RSD sector is divided into 
two groups - single-family houses and apartment buildings with similar end-processes as those in the COM sector.

The obtained results have been validated by comparing modelled and actual data for year 2018. The validation shows that modelled primary energy consumption of analysed sectors are comparable with the historical data. Therefore, the proposed structure can be used for sectors`energy consumption modelling.

Further research will be performed to analyse agriculture, transport and power sectors and to develop an overall energy system model of Latvia. To build up comprehensive energy system model additional research could include the combination of TIMES model with other methods like top-down modelling.

\section{ACKNOWLEDGEMENT}

This research is funded by the Ministry of Economics of the Republic of Latvia, project "Energy and climate modelling towards net zero emissions", project No. VPP-EM-2018/NEKP-0001.

\section{REFERENCES}

[1] Burandt T., Xiong B., Löffler K., Oei P. Y. Decarbonizing China's energy system - Modeling the transformation of the electricity, transportation, heat, and industrial sectors. Applied Energy 2019:255:113820. https://doi.org/10.1016/j.apenergy.2019.113820

[2] Andersen K. S., Termansen L. B., Gargiulo M., Gallachóirc B. P. Ó. Bridging the gap using energy services: Demonstrating a novel framework for soft linking top-down and bottom-up models. Energy 2019:169:277-293. https://doi.org/10.1016/j.energy.2018.11.153

[3] Wu Y. H., Liu C. H., Hung M. L., Liu T. Y., Masui T. Sectoral energy efficiency improvements in Taiwan: Evaluations using a hybrid of top-down and bottom-up models. Energy Policy 2019:132:1241-1255. https://doi.org/10.1016/j.enpol.2019.06.043

[4] Gravelsins A. et al. Modelling energy production flexibility: System dynamics approach. Energy Procedia 2018:147:503-509. https://doi.org/10.1016/j.egypro.2018.07.060

[5] Han S., Kim J. An optimization model to design and analysis of renewable energy supply strategies for residential sector. Renewable Energy 2017:112:222-234. https://doi.org/10.1016/j.renene.2017.05.030

[6] McCallum P. A multi-sectoral approach to modelling community energy demand of the built environment. Energy Policy 2019:132:865-875. https://doi.org/10.1016/j.enpol.2019.06.041

[7] Astudillo M. F., Vaillancourt K., Pineau P. O., Amor B. Can the household sector reduce global warming mitigation costs? Sensitivity to key parameters in a TIMES techno-economic energy model. Applied Energy 2017:205:486-498. https://doi.org/10.1016/j.apenergy.2017.07.130

[8] Karali N., Park W. Y., McNeil M. Modeling technological change and its impact on energy savings in the U.S. iron and steel sector. Applied Energy 2017:202:447-458. https://doi.org/10.1016/j.apenergy.2017.05.173

[9] Wiese F., Baldini M. Conceptual model of the industry sector in an energy system model: A case study for Denmark. Journal of Cleaner Production 2018:203:427-443. https://doi.org/10.1016/j.jclepro.2018.08.229

[10] Fleiter T. et al. A methodology for bottom-up modelling of energy transitions in the industry sector: The FORECAST model. Energy Strategy Reviews 2018:22:237-254. https://doi.org/10.1016/j.esr.2018.09.005

[11] Tash A., Ahanchian M., Fahl U. Improved representation of investment decisions in the German energy supply sector: An optimization approach using the TIMES model. Energy Strategy Reviews 2019:26:100421. https://doi.org/10.1016/j.esr.2019.100421

[12] Balyk O. et al. TIMES-DK: Technology-rich multi-sectoral optimisation model of the Danish energy system. Energy Strategy Reviews 2017:23:13-22. https://doi.org/10.1016/i.esr.2018.11.003

[13] Li P. H., Keppo I., Strachan N. Incorporating homeowners' preferences of heating technologies in the UK TIMES model. Energy 2018:148:716-727. https://doi.org/10.1016/j.energy.2018.01.150

[14] Bolwig S. et al. Review of modelling energy transitions pathways with application to energy system flexibility. Renewable and Sustainable Energy Reviews 2018:101:440-452. https://doi.org/10.1016/j.rser.2018.11.019

[15] Reveiu A., Smeureanu I., Dardala M., Kanala R. Modelling domestic lighting energy consumption in Romania by integrating consumers behavior. Procedia Computer Science 2015:52(1):812-818. https://doi.org/10.1016/j.procs.2015.05.137 
[16] Cayla J. M., Maïzi N. Integrating household behavior and heterogeneity into the TIMES-Households model. Applied Energy 2015:139:56-67. https://doi.org/10.1016/j.apenergy.2014.11.015

[17] Pfenninger S. Opening the black box of energy modelling: Strategies and lessons learned. Energy Strategy Reviews 2018:19:63-71. https://doi.org/10.1016/j.esr.2017.12.002

[18] Loulou R., Goldstein G., Kanudia A., Lettila A., Remme U., Noble K. Documentation for the TIMES Model PART I - Concepts and Theory. Energy Technology Systems Analysis Programme, 2016.

[19] Commission to the European Parliament and the Council, Climate action progress report. [Online]. [Accessed: 15.04.2020]. Available: https://eur-lex.europa.eu/legal-content/EN/TXT/?uri=CELEX\%3A52015DC0576

[20] Central Statistical Bureau of Latvia. Energy balance, TJ, thsd toe (NACE Rev.2). [Online]. [Accessed: 22.04.2020]. Available: http://data1.csb.gov.lv/pxweb/en/vide/vide_energetika_ikgad/ENG020.px/.

[21] Cabinet of Ministers. Regulation on building classification in Latvia. Latvijas Vestnesis 118, no. 118, 2018.

[22] The State Construction Control Bureau of Latvia. Average specific heating consumption. 2018. [Online]. [Accessed: 15.02.2020]. Available: http://bvkb.gov.lv/lv/content/videjais-ipatnejais-apkures-paterins-2.

[23] Ministry of Economics. Long-Term Strategy for Renovation of Buildings. Riga, 2017.

[24] Ministry of Economics. Valsts institūciju īpašumā, valdījumā un lietošanā esošās ēkas ar kopējo platību virs 250 m². 2019. (In Latvian)

[25] Cabinet of Ministers. Regulations Regarding Energy Certification of Buildings. Latvijas Vestnesis, 2013.

[26] Fuentes E., Arce L., Salom J. A review of domestic hot water consumption profiles for application in systems and buildings energy performance analysis. Renewable and Sustainable Energy Reviews 2017:81:1530-1547. https://doi.org/10.1016/j.rser.2017.05.229

[27] Roth K. W., Dieckmann J., Hamilton S. D., Goetzler W. Energy Consumption Characteristics of Commercial Building HVAC Systems Volume III : Energy Savings Potential. Building Technologies Program 2002:3(68370)

[28] Werner S. European space cooling demands. Energy 2016:110:148-156. https://doi.org/10.1016/j.energy.2015.11.028

[29] Pérez-Lombard L., Ortiz J., Pout C. A review on buildings energy consumption information. Energy and Buildings 2008:40(3):394-398. https://doi.org/10.1016/j.enbuild.2007.03.007

[30] Cabinet of Ministers. Labour Protection Requirements in Workplaces. Latvijas Vestnesis, 2009.

[31] Aman M. M., Jasmon G. B., Mokhlis H., Bakar A. H. A. Analysis of the performance of domestic lighting lamps. Energy Policy 2013:52:482-500. https://doi.org/10.1016/j.enpol.2012.09.068

[32] Kerimray A., Suleimenov B., De Miglio R., Rojas-Solórzano L., Amouei Torkmahalleh M., Gallachóir B. P. Ó. Investigating the energy transition to a coal free residential sector in Kazakhstan using a regionally disaggregated energy systems model. Journal of Cleaner Production 2018:196:1532-1548.

https://doi.org/10.1016/j.jclepro.2018.06.158

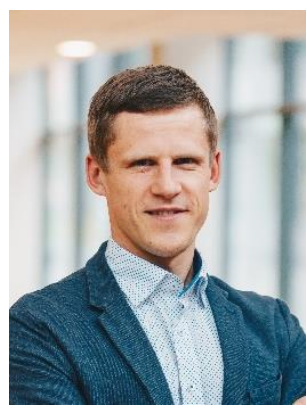

Dzintars Jaunzems, Dr. sc. ing., has a bachelor degree in environmental science (2004), a master degree in environmental science (2006) and doctor of science degree in engineering (2011) and bachelor's degree in business administration (2002). He works in the Institute of Energy Systems and Environment, Faculty of Electrical and Environmental Engineering at Riga Technical University from the year 2005, and since 2011 is a leading researcher and assistant professor. He worked as a Director in the energy service company RENESCO (2015-2019), as a Project Manager in RENESCO (2011-2015), as a Project Manager and as Researcher in the Riga Technical University (2005-2011). The main research interests are solar energy, sustainable development, energy efficiency and modelling.

E-mail: Dzintars.Jaunzems@rtu.lv

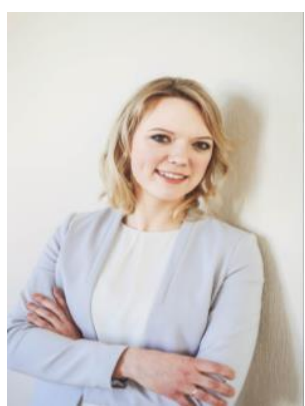

Ieva Pakere, M. sc. ing., researcher. Main research areas are district heating optimisation, solar thermal and power systems, mathematical modelling, RES and energy efficiency improvement of technological processes. Author of more than 20 scientific publications indexed in SCOPUS database with h-index 6.

E-mail: Ieva.Pakere@rtu.lv 

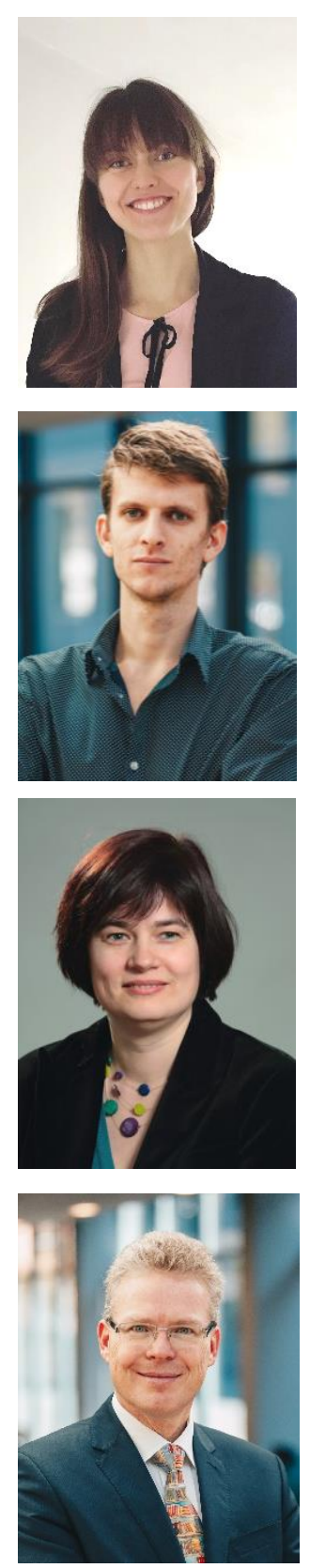

Signe Allena-Ozolina, M. sc. is a researcher and $\mathrm{PhD}$ student at Riga Technical University (RTU) Institute of Energy Systems and Environment, Latvia. In 2016 she has earned environmental sciences master degree from Faculty of Electrical and Environmental science RTU. Also, in 2014, she earned masters and, in 2012, bachelor degrees in social sciences in management from University of Latvia. Research interests are related to renewable energy and energy sector in general. She studies the development of energy sector of Latvia using TIMES modeling tool.

E-mail: $\underline{\text { Signe Allena-Ozolina@rtu.lv }}$

Ritvars Freimanis received M. sc. degree in Environmental Engineering by graduation both Riga Technical University and Vilnius Gediminas Technical University in 2019. Since 2017 he works as a scientific assistant at Institute of Environmental and Energy Systems at Riga Technical University, Riga. He is involved in EU research project RIBuild that develops guidelines on how to install thermal insulation on historic buildings.

E-mail: ritvars.freimanis@rtu.lv

Andra Blumberga, Dr. sc. ing., professor, works for Institute of Energy Systems and Environments, Riga Technical University since 2001. She has been working with energy efficiency since 1992. Her main research interest is energy efficiency both from technical and policy sides. She has managed many national and international research and other projects since 1999, e.g. 'Assessment on energy efficiency and use of renewable energy sources in Latvia by 2020 ', 'Climate Technology development modeling in energy sector', 'Energy strategy 2030 for Latvia', 'System Dynamics modeling for energy sector in Latvia'. She has been working as the World Bank energy expert for development of the Green Investment Scheme in Latvia. She is an author of more than 80 publications and 14 monographs.

E-mail: andra.blumberga@rtu.lv

ORCID iD: http://orcid.org/0000-0002-4712-4794

Gatis Bažbauers, Dr. sc. ing., has a diploma of thermal engineering (1990), master of science degree in mechanical engineering (1995), doctor of science degree in engineering (1999) and bachelor's degree in business administration (2002). He works in the Institute of Energy Systems and Environment, Faculty of Electrical and Environmental Engineering at Riga Technical University from the year 2000, and currently is a Professor. He worked as a Managing Director in the energy company "Vattenfall Latvia" (1995-2007), as a Project Manager in the energy consulting company "EEE" (1992-1993) and as an Assistant in the Riga Technical University (1990-1993). The main research interests are district heating systems and cogeneration, energy system planning and economics, renewable energy sources, eco-design, life cycle assessment.

E-mail: Gatis.Bazbauers@ rtu.lv

ORCID iD: https://orcid.org/0000-0001-6996-8472 